\title{
Distribution and Accumulation of Heavy Metals in Red Cedar (Cedrela odorata) Wood Seedling Grown in Dumpsite Soil
}

\author{
*AKINTOLA, OO; BODEDE, IA \\ Forestry Research Institute of Nigeria, P.M.B 5054 Jericho Hill, Ibadan, Oyo State, Nigeria \\ *Corresponding Author Email: toyinakintola $73 @$ gmail.com
}

\begin{abstract}
Recent technological advancements in industrialization and urbanization process have led to release of toxic contaminants like heavy metals in the environment. This study assessed the ability of Cedrela odorata to accumulate and distribute heavy metals such as $\mathrm{Cu}, \mathrm{Pb}, \mathrm{Zn}, \mathrm{Cd}$ and $\mathrm{Co}$ in their roots and shoots planted in dumpsite soil by determining the distribution factors and enrichment coefficients between soils and plant parts. Heavy metal concentrations (mg/kg) before planting were $\mathrm{Cu}$ (48.01-356.71), $\mathrm{Pb}(28.42-26.48), \mathrm{Zn}$ (39.99-437.88), $\mathrm{Cd}(0.69-9.59)$ and Co (16.88-29.22) while their concentrations after planting were $\mathrm{Cu}(8.12-226.56), \mathrm{Pb}(11.22-227.41), \mathrm{Zn}$ (7.66-321.51), $\mathrm{Cd}(0.31-4.78)$ and $\mathrm{Co}$ (3.21-14.11). Heavy metal concentrations $(\mathrm{mg} / \mathrm{kg})$ in roots were $\mathrm{Cu}(9.93-20.11), \mathrm{Pb}(7.26-15.21), \mathrm{Zn}(9.05-22.35), \mathrm{Cd}$ (0.11-0.99) and $\mathrm{Co}(4.56-6.11)$ and their concentration shoots of the plant were $\mathrm{Cu}(18.01-35.22), \mathrm{Pb}(9.01-17.51), \mathrm{Zn}$ (18.66-37.86), $\mathrm{Cd}$ (0.15-1.32) and Co (6.45-8.01). Enrichment coefficients and distribution factors were 0.1-1.21 and 1.292.08 respectively. Heavy metal concentrations in dumpsite soil were found to be greater than control soil.The reductionobserved in concentrations of heavy metals in soils after planting indicated theirenrichment in the plant tissues. Values of enrichment coefficients and distribution factors indicated the potential of Cedrela odorata as phytoextractor plant. This study has further proven the efficacy and ability of Cedrela odorata to accumulate and distribute heavy metals in its tissue parts. Thus Cedrela odorata seedlings can be used to clean or rehabilitate soils that are contaminated with the studied heavy metals.
\end{abstract}

DOI: https://dx.doi.org/10.4314/jasem.v23i5.6

Copyright: Copyright (C) 2019 Akintola and Bodede. This is an open access article distributed under the Creative Commons Attribution License (CCL), which permits unrestricted use, distribution, and reproduction in any medium, provided the original work is properly cited.

Dates: Received: 27 April 2019; Revised: 20 May 2019; Accepted 23 May 2019

Keywords: Heavy metal uptake, Cedrela odorata, Dumpsite, Enrichment Coefficients, Distribution Factors.

\section{INTRODUCTION}

Fast growing industrial and development in the past two decades have amplified the amount and miscellany of toxic and hazardous wastes in the environment. Heavy metal contamination in soil is one of the major environmental problems throughout the world. Metals with specific density of at least 5 times greater than that of water, $1 \mathrm{~g} \mathrm{~cm}-3$ are known as heavy metals and thus, have a specific density greater than $5 \mathrm{~g} / \mathrm{cm}^{3}$ (Kabata-Pendias, 2001; Adams, 2013) According to Brady (2002), heavy metals can be classified into two; essential and non-essential elements for living of organisms. Essential elements such as $\mathrm{Fe}, \mathrm{Mn}, \mathrm{Zn}, \mathrm{Cu}, \mathrm{Co}$ and $\mathrm{Mo}$, as $\mathrm{Ni}$ and $\mathrm{Cr}$ are beneficial elements that have known biological functions to microorganisms while $\mathrm{Cd}, \mathrm{Hg}, \mathrm{Pb}$ and $\mathrm{As}$ and As are considered as non-essential elements because they do not have significant functions. (Brady, 2002; Prataset al., 2013). Heavy metals, essential or not, can become toxic when their concentrations in the environment is excessive and adversely affect the growth and reproduction of organisms, even cause death (Alloway, 2001; Jarup, 2003). High concentrations of heavy metals in soil can inhibit microbial enzyme activity and reduces the diversity of populations of flora and fauna, causing infertility and increasing erosion. The transfer of heavymetals to man can occur through the ground (inhalation and ingestion of dust), food, water, air or skin (result of dermal absorption of contaminants from soil and water) (Chehregani and Malayer, 2007), Toxicological effects of heavy metals to humans, particularly on the central and peripheral nervous, gastrointestinal (GI), cardiovascular, hematopoietic and renal systems has been documented by (Adriano, 2001; Inoue, 2013; Prataset al, 2013). Heavy metal contamination can come from natural or anthropogenic origins such as soil erosion, natural weathering of the earth's crust, mining, industrial effluents, urban runoff; sewage discharge, insect or disease control agents applied to crops, and spent oil (Moraiset al., 2012; Jaishankaret al., 2014).Thus, heavy metals contamination has become aworldwide environmental concern with its potential ecological effect (Ani, 2006; Liu et al., 2009; Hu et al., 2017). Waste dumpsite is final place for all types of waste, either municipal solid waste, collected and transported directly to landfills, or industrial waste or other materials from waste treatment facilities

*Corresponding Author Email: toyinakintola73@gmail.com 
which are useless (Akintola, 2014). Because there will always be waste to be disposed of, landfill forms the basis of every waste management plan (Akintola, 2014). However, any site where waste is concentrated, processed or recycled and stored even for a short period of time may be a potential point source of heavymetal contamination. (Ideriah et al., 2010). Many researchers have studied the distribution and speciation of heavy metals in foods, drinking and river waters, agricultural soils, and environmental samples (Tusen et al., 2007; Yilmaz, 2007; Somaye et al., 2008). Forenvironmentalstudies, heavy metal uptakebyplants from contaminated soils is essential for using plants as biomonitors or hyperaccumulators. Hyperaccumulator species typically have one hundred times higher heavy metal concentration than other species growing in the same areas (Terry et al., 2000; Sors et al., 2005; Galeas et al., 2007). Plant species differ in their abilities to accumulate heavy metal (White et al., 2004, 2007). The distribution of heavy metal accumulator plants is generally controlledby contaminated soils, where their shoots can contain significant amount of heavy metals (White et al., 2007). Higher plants species vary widely in heavy metal uptake and accumulation in shoots and other edible parts can range between medium to high concentrations in solutions, soils, or shoots. Cedrela odorata is found in both primary and secondary evergreen to semi- deciduous lowland or lower montane rainforest. It demands light and does not tolerate waterlogging or flooding (Torre et al., 2008). The trees are best planted in regions with very fertile soils and with perfect drainage that results in the good aeration of the soil required by the root system. It is not demanding of soil nutrients, tolerating soils with high concentrations of nutrient elements and heavy soils (Torre et al., 2008). Study carried out by Akintola (2004) on Lapite waste dumpsite, one of the largest dumpsite belonging to Ibadan Waste Management Authority (IBWMA) shown the soil in and around the dumpsite has been contaminated with heavy metals as a result of toxic and hazardous waste be deposited on the site. Thus, there is need for the studied site to be remediated from the contaminants (heavy metals). This study assessed the ability of Cedrela odorata to accumulate and distributes heavy metals $(\mathrm{Cu}, \mathrm{Cd}, \mathrm{Pb}$, $\mathrm{Zn}$ and $\mathrm{Co}$ ) in their roots and shoots planted in dumpsite soil by determining the distribution factors and enrichment coefficients between soils and plant parts.

\section{MATERIALS AND METHODS}

Study location: A pot experiment was carried out in Screen house of Forestry Technology Department, Federal College of Forestry, Ibadan, Oyo state. The experimental site lies between Latitude $7^{0} 26^{\prime} \mathrm{N}$ and
Longitude $3^{0} 54$ 'E. The climate of the area is tropical. The annual rainfall ranges from $1400 \mathrm{~mm}-1500 \mathrm{~mm}$ and average relative humidity of about $65 \%$, the average temperature is $31.8^{\circ} \mathrm{C}$. The area is dominated by two seasons: the dry season and rainy season. The rainy season usually begins from November to March, while the rainy season starts from April to October (FRIN Meteorological Station, 2015)

Procurements of Experimental Materials:Topsoil used in this study was collected from a dumpsite located in Lapite village, within Akinyele Local Goverment area, Ibadan. It is situated between old Oyo road and newly constructed Ibadan- Oyo express road (Fig.1). The dumpsite covers an area of 200 by 400 meters, sited on high elevation; weathered and fractured rocks (Akintola, 2014). Tones of wastes generated and collected from various locations in Ibadan and its environs are deposited on a daily basis onto the dumpsite, giving rise to large heap of waste of varying composition, up to $3.0 \mathrm{~m}$ high relative to the ground surface (Akintola, 2014). Dumping at the site is unrestricted and industrial, agricultural, domestic and medical wastes (including used syringes) are strewn all over the dumping site.Some of the waste from the dump ends up into the stream thus extending environmental and health risks to the communities living within the vicinity as well as those living downstream who could be using the water for domestic and agricultural purposes (Akintola, 2014). Lapite dumpsite and its environ are underlain by Basement Complex rocks of southwestern Nigeria. The major rock types in area and it's environ are migmatite and banded gneisses. Composite topsoil was collected within the dumpsite and about $500 \mathrm{~m}$ lateral distance on the upslope side of the site at the depth of $0.20 \mathrm{~m}$. Topsoil collected within dumpsite is T1 while those collected from the upslope was control soil (T2). Seeds of Cedrela odorata were obtained from Forestry Research Institute of Nigeria in Ibadan. The soil sample was air-dried and sieved using $2 \mathrm{~mm}$ sieve to remove stones, roots and other materials that may be detrimental to the emergence of the young plants from the seeds.

Experimental Methods and Design: 200 seeds of cedrela odorata were sown in germination boxes which were watered daily and monitor for germination. A sample of $2 \mathrm{~kg}$ of soil of the two treatments (dumpsite soil, T1 and control soil, T2) was filled into a plastic pot perforated, 3-4 holes at the base. 60 healthy seedlings was picked from germination boxes and transplanted into polythene pot of $30 \mathrm{~cm}$ by $15 \mathrm{~cm}$ containing $2 \mathrm{~kg}$ of soil at different treatment levels to ensure normal growth of the seedlings. The experiment consisting two treatments, 
replicated ten times making a total of twenty (20) pots for the plan and were arranged in a completely randomized design.. Inter-culture operation such as weeding and watering was done every day. The experiment lasted for 12 weeks (3 months). The experimental pots were watered every three days, and subsequently during the course of the experiment, the weeding of the pots was done by hand. Growth parameters; plant height, stem diameter and leaf production were assessed fortnightly for three months. At the end of pot experiment, plant biomass was determined; roots, stems and leaves of the plants. Soil samples before and after planting were collected and taken to the laboratory for chemical analysis.

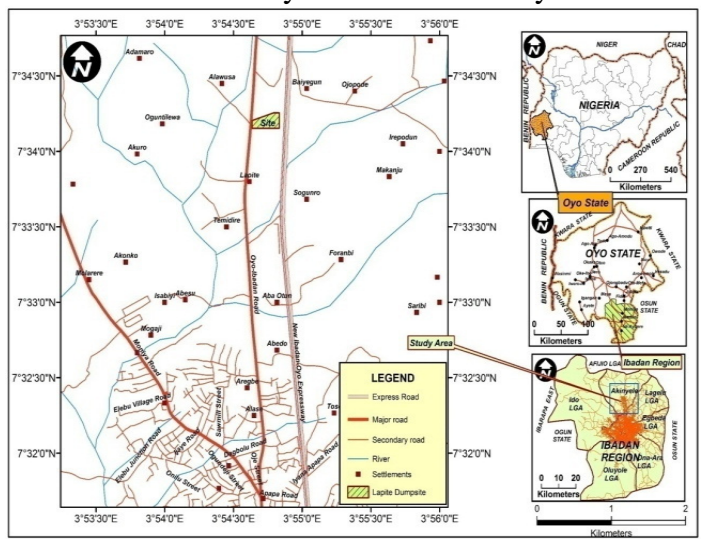

Fig. 1 Location map of Lapite dumpsite (Akintola, 2014)

Composite soil samples (before and after planting) from eeach of the treatment pots were collected and analyzed for physiochemical and heavy metal analysis. Particle size and texture of soil samples were determined and soil $\mathrm{pH}$ was measured by means of a glass electrode $\mathrm{pH}$ meter by dipping the glass electrode into a 1:1 according to Thomas (1996). Soil organic carbon was determined by the chromic acid digestion method of Walkley and Black (Sparks, 2003). Plant parts (roots, stems and leaves) and soil samples were analyzed for heavy metal $(\mathrm{Cu}, \mathrm{Zn}, \mathrm{Pb}$, $\mathrm{Cd}$ and $\mathrm{Co}$ ) concentrations using Inductively Couple Plasma Mass Spectrometry (ICP-MS) method. Enrichment Coefficients of root and shoot (EC) were calculated by dividing concentration of heavy metal in plant roots by their concentrations in soil after planting. This value was used as an index for the accumulation of trace elements in plant parts or the transfer of elements from soil to plant parts (Chen et $a l$., 2005).Distribution Factors (DF) are obtained by calculating the ratios of heavy metals or elements in plant shoot to that in plant root. In metal accumulator species, distribution factors greater than 1 are common.Analysis of variance (ANOVA) for the growth parameters and heavy metals concentrations in the samples were done using the Duncan's multiple range test DMRT $(\mathrm{p}=0.05)$ method. The statistical variations were considered significant at $\mathrm{p}<0.05$. Data were computed using graphicalmethods.

\section{RESULTS AND DISCUSSION}

Properties of Growing Media: Physiochemical characteristics of the soil before and after planting are presented in table 1 . Grain size distribution of the treatment soils were $71-75 \%$ sand, $14-16 \%$ silt and $10-13 \%$ clay. Texture is an important soil characteristic that plays important role in soil management and crop production.Loamy sandy texture soil is suitable for seedling growth and development because it contains high nutrients, CEC and high water holding capacity. The $\mathrm{pH}$ of the treatment soils after planting (5.56 -5.99) decreased when compared to the treatments before planting (5.99 - 6. 70). Soil pH affects all the chemical, physical and biological properties of soil (Brady and Weil, 2002). Chemical element accumulation in plants not only depends on their absolute content in soil but also on the level of soil acidic-alkaline and reductive oxidative conditions and content of organic matter (Ovisagie and Ndiokere, 2008). Soil pH affects the solubility and bioavailability of elements in the soil for plant uptake (Ovisagie and Ndiokere, 2008).Total nitrogen, phosphorus and organic carbon content in the soils after planting were lower compared to those at the onset of the experiment due to the effects of the plant growing in the soils. Organic matter content describes the levels of mineral elements for plants development and growth. Thus, it plays an important role in soil structure, water retention, cation exchange and in the formation of complexes (Alloway, 2001). Organic matter content of soils before and after plantings of dumpsite (T2) and control (T1) were 5.88- 3.41\% and 2.31-2. $26 \%$ respectively. High organic matter content in the soil in the $\mathrm{T} 2$ can be attributed to decomposition and composting processes of the animals waste (which include animal's dung, body parts and blood), plants/vegetable matter and polymer or plastic materials (as the site is also used as a municipal solid waste dump) and also washed away agricultural chemicals (pesticides, insecticides and herbicides) that passed through the dump sit and this confirms why farmers consciously choose to farm on such site ( Ebong et al.,2008).Solid waste dumpsites have been reported to be rich in organic matter which is the source of nitrogen and phosphorus which enhance soil fertility and promote plant growth. Total nitrogen in the dumpsite soil $(0.35-0.62 \%)$ is higher compare to control soil (0.11- 0.22). High phosphorus concentration in dumpsite soils than control soil could be attributed to the presence of high amount of organic matter and plants decomposition (table 1). 
Table 1: Physiochemical properties of the growing media

\begin{tabular}{lllllllll}
\hline Treatments & Planting & $\mathrm{pH}$ & $\begin{array}{l}\text { OMC } \\
(\%)\end{array}$ & $\begin{array}{l}\mathrm{N} \\
(\%)\end{array}$ & $\begin{array}{l}\mathrm{P} \\
(\mathrm{mg} / \mathrm{kg})\end{array}$ & $\begin{array}{l}\text { Sand } \\
(\%)\end{array}$ & $\begin{array}{l}\text { Silt } \\
(\%)\end{array}$ & $\begin{array}{l}\text { Clay } \\
(\%)\end{array}$ \\
\hline $\mathrm{T} 1$ & Before & 5.99 & 2.31 & 0.21 & 34.22 & 75 & 15 & 10 \\
& After & 5.56 & 1.26 & 0.11 & 30.18 & 74 & 14 & 12 \\
$\mathrm{~T} 2$ & Before & 6.70 & 5.88 & 0.62 & 105.22 & 71 & 16 & 13 \\
& After & 6.05 & 3.41 & 0.35 & 97.99 & 72 & 15 & 13 \\
\hline
\end{tabular}

Growth Performance of $C$. Odorata in Treatment Soils: Weekly mean values of seedling heights stem diameter and leaf production were presented in figure 1 -3. It was observed that the grow parameters in dumpsite soils (T1) was greater than those in control site from week 1 to 6 , after which a reduction was noticed from week 6 to 12 . The increase in the growth in the first six weeks after transplanting could be attributed to the soil being rich in organic matter which is the source of most of the nitrogen and phosphorus which enhances soil fertility and promote plant growth (Ideriahet al., 2010). Also the activities of soil organisms in the decomposition of these wastes may have accounted for the rich nutrient contents of the soil which in turn has enhanced the growth of $C$. Odrata seedlings (Obuteet al., 2010; Amos-Tautuaet al., 2014). Reduction in the growth of the plants in T1 from week 6 to week 12 could be attributed to the presence of high contaminants (heavy metals) from the wastes which might have inhibited the plant growth (Akintola, 2014). The growth parameters of $C$. odorata plants were significantly influenced by the toxicity of contaminated soils $(\mathrm{P} \leq 0.05)$. Generally, the reduction the growth parameters noticed from $\mathrm{T} 1$ when compared to T2 could be due to interference with the soil-water-relation as well as nutrient immobilization and the presence of heavy metals (Peralta-Videa et al., 2002; Akintola, 2019). The biomass of the plant varied significantly. The results showed that biomass production for plants gradually increased with treatments (Table 2). It showed that the amounts of heavy metals in the soils did not affect biomass production or induce phytotoxicity symptoms in the plant.

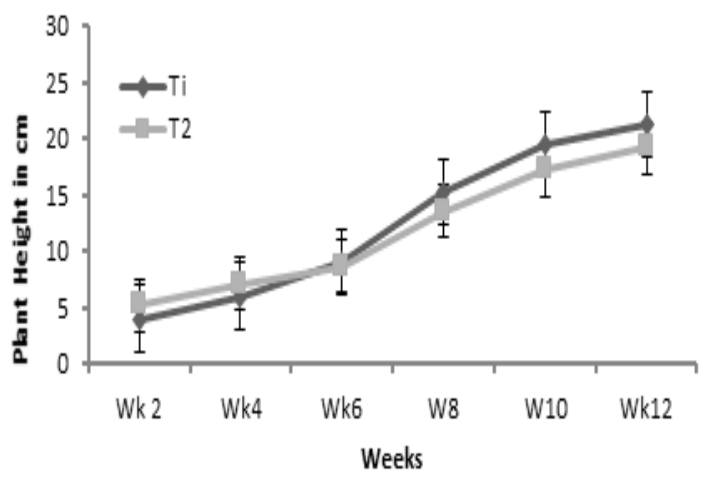

Fig1: Weekly mean values of Plant Height

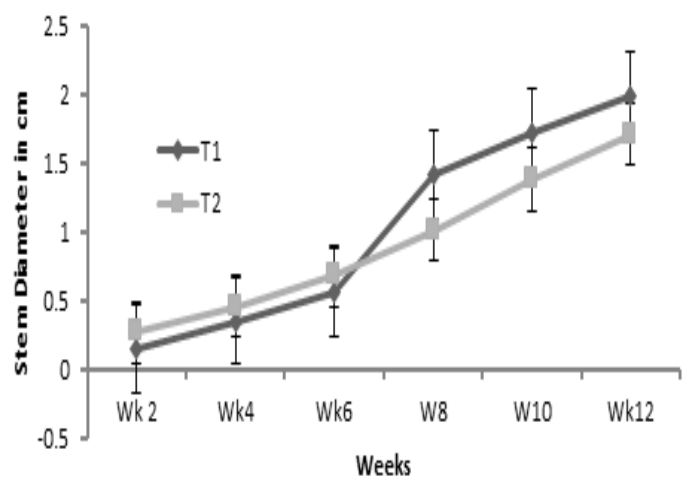

Fig2: Weekly mean values of Stem Diameter

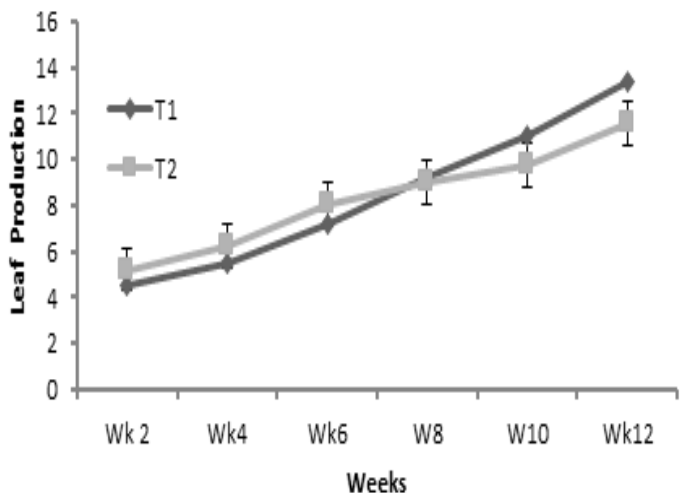

Fig 3: Weekly mean values of leaf production

TABLE 2. Mean values of biomass production of C. Odorata \begin{tabular}{llll}
\multicolumn{4}{c}{ Seedlings } \\
\hline Treatment & Stem $(\mathbf{g})$ & $\operatorname{Root}(\mathbf{g})$ & Leaf $(\mathbf{g})$ \\
\hline T1 & $92.20^{\mathrm{b}}$ & $94.00^{\mathrm{b}}$ & $105.70^{\mathrm{b}}$ \\
T2 & $96.90^{\mathrm{a}}$ & $119.50^{\mathrm{a}}$ & $140.70^{\mathrm{a}}$ \\
\hline Mean values with the different letter are significant different \\
$(P<0.05)$ from each other at different treatment levels.
\end{tabular}

Heavy Metals in Treatment Soils: Common heavy metal contaminants which can come from industrial activities, such as mining and smelting of metalliferous ores, electroplating, gas exhaust, energy and fuel production, fertilizer and pesticide application, and generation of municipal wastes are $\mathrm{Cd}, \mathrm{Cr}, \mathrm{Cu}, \mathrm{Hg}, \mathrm{Pb}$, and $\mathrm{Zn}$ (Kabata-Pendias, 2001). Heavy metals concentrations in the potting media before and after planting (BP and AP) are shown in Table 2. Heavy metal concentrations in soil before planting were found to be significantly higher than after planting. Heavy metal concentrations in dumpsite soils (T2) were higher than those of control (T1). The 
observed high heavy metal concentrations in dumpsite soils can be related to high deposit of metal- rich waste in the area. This may also be attributed to the ability of the soil to retain heavy metals from the wastes and contaminant in solution may become attached to the surface of the soil (solids) particles through mechanisms, which seem to satisfy the forces of attraction from the soil solids (Yong, 2001). Heavy metals, being positively charged, are electrostatically attracted to the negative charges on the clay particles (Yong, 2001).

Table 3: Heavy metals concentration in soil before and after planting

\begin{tabular}{lllllll}
\hline \multirow{2}{*}{ Treatments } & Planting & \multicolumn{5}{c}{ Heavy metals in mg/kg } \\
\cline { 3 - 7 } & & $\mathrm{Cu}$ & $\mathrm{Zn}$ & $\mathrm{Pb}$ & $\mathrm{Cd}$ & $\mathrm{Co}$ \\
\hline T1 & Before & 48.01 & 39.99 & 28.42 & 0.69 & 16.88 \\
& After & 8.21 & 7.68 & 11.22 & 0.31 & 5.21 \\
T2 & Before & 356.71 & 437.88 & 260.48 & 9.59 & 27.22 \\
& After & 226.56 & 321.51 & 227.41 & 4.75 & 14.11 \\
\hline
\end{tabular}

Organic complexation of metals may also occur when humic material binds metals into a ring-typed structure most commonly a chelate (Akintola, 2019). Observed reductions in the heavy metal concentrations in soil after planting can be attributed to the ability of $C$. odorata to uptake heavy metals from the soils. Low reduction in $\mathrm{Pb}$ concentrations compared to other heavy metal concentrations after planting may be due to its not essential to plants and its toxicity to plants, animals, and microorganisms (Akintola, 2019). High reduction in $\mathrm{Zn}$ and $\mathrm{Cu}$ concentration in the growth media after planting may be due to their important in metabolic activities of plants (Marcel, 2006). Alkorta et al., (2004) stated that most frequently inorganic pollutant in the soils is lead $(\mathrm{Pb})$ and is not an essential element but can be toxic even at low concentrations to plants, animals and human and above $400 \mathrm{mg} / \mathrm{kg}$ can be hazardous to human health (USEPA, 2001). The significant reduction of heavy metals in the growth media showed the level of heavy metal enrichment in C. odorata plants.

Enrichment Coefficients and Distribution Factors: Assessing heavy metal uptake by plants from contaminated soils is very important for environmental studies because of the possibility of using plants as biomonitors or hyper accumulators. Enrichments Coefficients and distribution factors of heavy metals in plant tissues are important to assess the potential and effectiveness of plant in removing heavy metals from contaminated soils (Sasmaz, 2009; Akintola, 2019). Heavy metal enrichment in the $C$. odorata plants parts are shown in Table 4.

A significantly influenced was noticed in all the treatments $(\mathrm{p} \leq 0.05)$. The results indicated that the $C$. odorata plants accumulated different levels of $\mathrm{Cu}, \mathrm{Pb}$, $\mathrm{Zn}, \mathrm{Cd}$ and $\mathrm{Co}$ in their parts, thus showing their tolerance for these metals. The roots of $C$. odorata plants accumulated lower concentrations of heavy metal when compared to the shoots of the plant (Table3).
Table 4: Heavy metal concentration in odorata plants' tissues

\begin{tabular}{lllllll}
\hline Treatments & Plant & \multicolumn{6}{l}{ Heavy metals in $\mathbf{~ m g} / \mathbf{k g}$} \\
\cline { 3 - 7 } & Tissues & $\mathrm{Cu}$ & $\mathrm{Zn}$ & $\mathrm{Pb}$ & $\mathrm{Cd}$ & $\mathrm{Co}$ \\
\hline T1 & Root & 9.93 & 9.05 & 7.26 & 0.11 & 4.56 \\
& Shoot & 18.01 & 18.66 & 9.01 & 0.15 & 6.45 \\
T2 & Root & 20.11 & 22.35 & 15.21 & 0.99 & 6.11 \\
& Shoot & 35.22 & 37.86 & 17.51 & 1.32 & 8.01 \\
\hline
\end{tabular}

Table 5: Values of Enrichment coefficients and Distribution

\begin{tabular}{lllll}
\multicolumn{4}{c}{ Heavy } & \multicolumn{3}{c}{ Enctors } \\
Metal & $\begin{array}{l}\text { Enrichment } \\
\text { Coefficients (EF) }\end{array}$ & $\begin{array}{l}\text { Distribution } \\
\text { (DF) }\end{array}$ \\
\cline { 2 - 5 } & T1 & T2 & T1 & T2 \\
\hline Cu & 1.21 & 0.10 & 1.81 & 1.75 \\
Zn & 1.19 & 0.10 & 2.08 & 1.69 \\
Pb & 0.65 & 0.10 & 1.24 & 1,16 \\
Cd & 0.35 & 0.21 & 1.36 & 1.33 \\
Co & 0.86 & 0.43 & 1.41 & 1.37 \\
\hline
\end{tabular}

Values of Enrichment coefficients (EC) and Distribution Factors (DF) were presented in table 5. Enrichment coefficient values were lower in plant grown in dumpsite soils when compared to control soils and could be attributed to the higher concentration of heavy metals in the dumpsite soil and it will take a longer time for the plants to accumulate higher amount of it. But in the case of control soil, the concentrations of the heavy metals were lower, so the plants took the one it can tolerate within the time of the experiment. Thus, heavy metal uptake by plants from soil depends on the level of metal concentrations in the soil, time and other factors. Distribution factor (DF) of heavy metals from the soil to $C$. odorata plant's parts is high $(>1)$ indicating the ability of the plants to uptake heavy metal from the soil and distribute it to different parts of its tissue. This value indicates that $C$. odorata can be a very efficient bioaccumulator plant for heavy metal in contaminated environments. It can be used to clean or rehabilitate soil and areas contaminated by $\mathrm{Cu}, \mathrm{Zn}, \mathrm{Pb}, \mathrm{Cd}$ and $\mathrm{Co}$.

Conclusion: The significant differences observed in concentrations of heavy metals in soils before and after planting indicated their enrichment in the plant tissues. Enrichment coefficients and distribution 
factors indicated the potential of Cedrela odorata as bioaccumulator plant. This study has further proven the efficacy and ability of Cedrela odorata to accumulate and distribute heavy metals in its tissue parts. Thus, Cedrela odorata seedlings can be used to clean or rehabilitate soils that are contaminated with the studied heavy metals.

\section{REFERENCES}

Adams, A; Raman, A; Hodgkins, D (2013). How do the plants used in phytoremediation in constructed wetlands, a sustainable remediation strategy, perform in heavy-metalcontaminated mine sites. Water and Environ. 27(3):373-386.

Adriano, DC (2001). Trace elements in terrestrial environments: Biogeochemistry; Bioavailability and Risks of Metals. 2nd ed. Springer-Verlag New York, Berlin Heidelberg.

Akintola, OO (2019). Heavy Metal Uptake and Growth Response of Jatropha curcas Linnaeus Seedlings in Spent Oil Contaminated Soil. Inter. J. Appl. Res. Technol., 8(2): $106-114$.

Akintola, OO (2014). Geotechnical and Hydrogeological assessment of Lapite waste dumpsite in Ibadan, Southwestern Nigeria. Unpublished $\mathrm{PhD}$ Thesis, University of Ibadan, 307pp.

Alkorta, I; Herna, AJ; Becerril, JM; Amezaga, I; Albizu, I; Garbizu, C (2004). Recent findings on the Phytoremediation of soil contaminated with environmentally toxic heavy metals and metalloids such as zinc, Cadmium, lead and arsenic. Environ. Sci. Biotech., 3: 71-90.

Alloway, BJ (2001). Heavy metals in soils. 2nd Ed. Glasgow G64 2NZ, UK: Blackie Academic and Professional, Chapman \& hall Publishing.

Amos-Tautua, BMW; Onigbinde, AO; Ere, D (2014). Assessment of some heavy metals and physiochemical properties in surface soils of municipal open waste dumpsite in Yenagoa, Nigeria. Afr. J. Environ. Sci. Technol., 8 (1):41-47.

An, YJ (2006). Assessment of comparative toxicities of lead and copper using plant assay. Chemosphere. 62:1359-1365.

Brady, NC and Weil, RR (2002). The Nature and Properties of Soils.13th ed. Upper Saddle River, NJ: Prentice-Hall, Inc.

Chehregani, A; Malayer, B (2007). Removal of Heavy Metals by Native Accumulator Plants. Int. J. Agric. Biotech. 9(3):462-465.
Chen, SB; Zhu, YG;Hu, QH (2005). Soil to plant transfer of $238 \mathrm{U}, 226 \mathrm{Ra}$ and $232 \mathrm{Th}$ on $\mathrm{U}$ mining-impacted soil from southeastern China. J. Environ. Radioac. 82: 223-236.

Ebong, G.A; Akpan, MM; Mkpenie, VN (2008). Heavy Metal Contents of Municipal and Rural Dumpsite Soils and Rate of Accumulation by Carica papaya and Talinumtriangularein Uyo, Nigeria. E-J. Chem. 5(2): 281-290.

FRIN Meteorological Station (2015). Information on the climate condition on the study area.Forestry Research Institute of Nigeria, Ibadan.

Galeas, ML; Zhang, LH; Freeman, JL; Wegner, M; PilonSmits, EAH (2007). Seasonal fluctuations of selenium and sulphur accumulation in selenium hyperaccumulators and related non accumulators. New Phytologist. 173:517-525.

Hu, B; Zhou, J; Liu, L; Meng, W; Wang, Z (2007). Assessment of heavy metal pollution and potential ecological risk in soils of Tianjin Sewage Irrigation Region, North China. J. Environ. Anal. Toxicol. 7(1):1-6.

Ideriah, TJK; Harry, FO; Stanley, HO; Igbara, JK (2010). Heavy metal contamination of soils and vegetation around solid waste dumps in Port Harcourt, Nigeria. J. Appl. Sci. Environ. Manage. 14 (1):101-109.

Inoue, KI (2013). Heavy metal toxicity. J Clin Toxicol.3:1-2.

Jaishankar, M; Tseten, T; Anbalagan, N; Mathew, BB Beeregowda KN (2014). Toxicity, mechanism and health effects of some heavy metals. Interdisc Toxicol..7(2): 60-72.

Jarup, L (2003). Hazards of heavy metal contamination. British Medical Bulletin. 68(1):167-182.

Kabata-Pendias, A (2001). Trace Elements in Soils and Plants, CRC Press, Boca Raton, Fla, USA, 3rd edition, 2001.

Liu J; Li Y; Zhang, B; Cao, J; Cao, Z (2009). Ecological risk of heavy metals in sediments of the Luan River source water. Ecotoxicol. 18:748-758.

Marcel, VDP (2006). Soil and water contamination from molecular to catchment scale. London: Lewis Publishers.

Morais, S; Costa, FG; Pereira, ML (2012). Heavy metals and human health. In: Oosthuizen $J$, editor. Environmental health - emerging issues and practice. Croatia China, Intech.227-246 
Obute, CC; Ndukwu, BC; Eze, E (2010). Changes in species diversity and physic-chemical properties of plants in abandoned dumpsites in parts of Port Harcourt, Nigeria. Scientia Africana, 9(1): 181-193.

Oliver, DP; Tiller, KG; Alston, AM; Cozens, GD; Merry, RH (1998). Effect of soil $\mathrm{pH}$ and applied cadmium on cadmium concentration in wheat grain. Aust. J. Soil Res. 36:571-583

Orji, CN; Abdulrahman, FW; Isu, NR (2018) Assessment of heavy metal pollution in soil from an automobile mechanic workshop in Abuja. Asian J Environ Eco. 6(1):114.

Oviasogie, PO; Ndiokwere, CL (2008). Fractionation of lead and cadmium in refuse dump soil treated with cassava milling effluent. J. Agric. Environ. 9:10-16

Peralta-Videa, J.; Martha, LP; Mahesh, Narayan, GS; Gardea-Torresdey, J (2009). The biochemistry of environmental heavy metal uptake by plants: Implications for the food chain. Inter. J. Biochem. cell Biol. 41:1665-1677.

Pratas J, Favas, P.J. C and Dsouza, R (2013). Phytoremedial assessment of flora tolerant to heavy metals in the contaminated soils of an abandoned $\mathrm{Pb}$ mine in Central Portugal. Chemosphere. 90(8):22162225 .

Sasmaz, A (2009). 'The distribution and accumulation of selenium in roots and shoots of plants naturally grown in the soils of Keban'sPb-Zn-Fmining area, Turkey. Inter. J. Phytoremed., 11:4,385 - 395

Somay, AM; Gemici, U; Filiz, S (2008). Hydrogeochemical investigation of Kucuk Menderes River coastal wetland, Selcuk-Izmir, Turkey. Environ. Geol. 55, 149-164.

Sors, TG; Ellis, DR; Salt, DE (2005).Selenium uptake, translocation, assimilation and metabolic fate in plants. Photosyn. Res. 86, 373-389.
Sparks, DL (2003). Environmental soil chemistry. Academic Press, UK.264 pp.

Terry, N; Zayed, AM; De Souza, MP; Tarun, AS (2000). Selenium in higher plants. Ann. Reviews Plant Physiol. Plant Mol. Biol. 51, 401-432.

Torre, A; De la,Lopez, C; Yglesias. E; Cornelius, JP (2008). Genetic AFLP diversity of nine Cedrelaodorata populations in Madre de Dios, Southern Peruvian Amazon. Forest Ecol. Manag. 255 ; 334-339

Tuzen, M; Sayg1, K.O; Soylak, M. (2007). Separation and Speciation of Selenium in Food and Water Samples by the Combination of Magnesium Hydroxide Coprecipitation-Graphite Furnace Atomic Absorption Spectrometric Determination, Talanta 71, 424-429.

US-EPA (2001). Lead, identification of dangerous levels, final rule. Code of Fed Reg. 66: 1206 -1240.

White, PJ; Bowen, HC; Marshall, B.and Broadley, M.R. (2007). Extraordinarily High Leaf Selenium to Sulfur Ratios Define 'Se-Accumulator' Plants. Ann. Bot. 100 (1), 111-118.

White, PJ; Bowen, HC; Parmaguru, P; Fritz, M; Spracklen, WP; Spiby, RE; Meacham, MC; Mead, A; Harriman, M; Trueman, BM; Smith, LJ; Thomas, B; Broadley M.R. (2004).Interactions between selenium and sulphur nutrition in Arabidopsis thaliana. $J$. Exper. Botany 55, 1927-1937.

Yilmaz, DD (2007). Bioaccumulation and distribution of heavy metals between different compartments of the Kizilirmak River (Turkey). Fresenius Env. Bull. 16(1), 14-18.

Yong, RN (2001). Geoenvironmental engineering: contaminated soils, pollutant fate and mitigation. CRC Press, Florida. 307 pp. 